\title{
Distribution of Polycyclic Aromatic Hydrocarbons in Surface Water of Elelenwo River, Rivers State, Niger Delta Nigeria
}

\author{
Edori Onisogen Simeon \\ Department of Chemistry Ignatius Ajuru University of Education, Rumuolumeni, Port Harcourt, Nigeria
}

Email address:

onisogen.edori@yahoo.com

\section{To cite this article:}

Edori Onisogen Simeon. Distribution of Polycyclic Aromatic Hydrocarbons in Surface Water of Elelenwo River, Rivers State, Niger Delta Nigeria. International Journal of Environmental Monitoring and Analysis. Vol. 8, No. 2, 2020, pp. 23-26. doi: 10.11648/j.ijema.20200802.11

Received: March 2, 2020; Accepted: March 16, 2020; Published: May 27, 2020

\begin{abstract}
The incidence of river pollution is a common place all over the world. Polycyclic aromatic hydrocarbons (PAHs) presence in the environment is on the increase. Water samples collected from Elelenwo River were analyzed for PAHs concentrations. The analysis was achieved after extraction with dichloromethane and n-hexane in a soxhlet extractor. Thereafter, gas chromatography-mass spectrometry (GC-MS) was used to separate and identify the different components of PAHs in the surface water samples. The result obtained showed the presence of 13 priority PAHs from the river. Three priority PAHs (fluorene, benzo (a) anthracene and chrysene) were not detected from any of the stations examined. Different classifications showed that the mean value for $2-3,4,5$ and 6 ring members were $0.067 \pm 0.038,0.013 \pm 0.005,0.08 \pm 0.00$ and $0.067 \pm 0.009 \mathrm{mg} / \mathrm{L}$ respectively. Thus indicating that the occurrence and abundance of the ring sizes were in the order of $5>6$ $+2-3>4$. Diagnostic ratio for origin identification in the river showed only pyrogenic source of contamination, thus implication human influence on the origin of the PAHs in the river water. Authorities involved with administration, management and enforcement of contaminant / pollutant discharge should channel their efforts to curb the incidence of outburst of PAHs pollution.
\end{abstract}

Keywords: Polycyclic Aromatic Hydrocarbons, Elelenwo River, Contamination, Distribution, Pyrogenic, Petrogenic

\section{Introduction}

Polycyclic aromatic hydrocarbons (PAHs) is composed of an enormous group of chemical combinations that are basically formed from partial incineration of fossil fuels. At low combustion temperatures, branched chain alkyl groups are formed from the parent PAHs compounds, but increase in combustion temperatures, reduces the formation of side chained PAHs. The predominance of any category of PAHs in any medium is a function of the temperature under which they were produced [1].

Nearly the family members of PAHs are predisposed to distribution on a comprehensive scale. Despite the fact that they have the capacity to remain in the environment for a long time, they possess the characteristics of partial volatility when subjected to conditions in the environment that changes between the earth's atmosphere repeatedly at varying or inconsistent temperature cycles $[2,3]$.
The nature and characteristics of the individual compounds of PAHs is dependent on the ring size and the pattern of the arrangement and linkage of the rings. PAHs are hydrocarbon compounds, but sometimes the carbon atom at a particular position may be substituted with a heteroatom [4]. PAHs are not readily soluble in water and so are described as being lipophilic in nature and thus their concentration is very low in aquatic media [5]. The solubility of PAHs in aquatic environment is determined by their molecular weight. this pre-supposes that the heavier PAHs are less soluble than the lighter PAHs [6]. Due to the hydrophobicity of PAHs, when they are deposited on surface water, they sink to the bottom to finally settle on the surface of sediment [7]. The presence of PAHs in any environment is due to a combination of human activities and natural factors [8].

The origin or sources of PAHs may either be pyrolytic 
(burning or sweltering processes) or petrogenic, which includes petroleum, biogenic and diagenic sources [9, 10]. The composition of PAHs is a reflection of the origin and derive sources [11]. The predominance of the lighter weight PAHs is mostly associated with natural resources (petrogenic), while the heavier PAHs is a consequence of combustive processes (pyrolytic) [12].

\section{Materials and Methods}

Water samples were composed together from Elelenwo River at different points in the month June. The samples were collected three times within the period from three different stations. The samples were taken from a depth of $40 \mathrm{~cm}$ below surface water against the flow of water current. The samples were immediately put in ice-cold ice pack and straightaway conveyed to the laboratory. Liquid-liquid extraction using a mixture of dichloromethane and n-hexane of $50 \mathrm{ml}$ each to extract the PAHs from the water [13]. Extraction was achieved after the water samples had been previously filtered with a Whatman filter paper. The filtration was done to remove freely floating particle and small solid fragments in the water. The extracts were concentrated to 2 $\mathrm{ml}$ with the aid of a rotary evaporator. The final volume was put into a gas chromatography (GC) that has been equipped with flame ionization detector (FID) with nitrogen as the carrier gas [5]. The gas chromatography examination was employed on a fused silica vessel support $60 \mathrm{~m}$ long, 0.25 $\mathrm{mm}$ diameter and a film width of $0.5 \mathrm{ml}$.

The obtained concentrations of the different PAHs constituents were subjected to source identification and diagnosis using the appropriate mathematical ratios $[10,14]$ and the sources apportioned based on the outcome of the ratios of the different classes of PAHs [14].

\section{Results and Discussion}

The concentrations of the constituents of the polycyclic aromatic hydrocarbons is shown in Table 1. In the Akpajo location, eight of the constituents (acenapthylene, fluorine, phenanthrene anthracene, pyrene benzo (a) anthracene, chrysene and benzo $(\mathrm{g}, \mathrm{h}, \mathrm{i})$ pyrene) were not detected. The total concentration of PAHs in the Akpajo location was 0.19 $\mathrm{mg} / \mathrm{L}$.

At the Rumuwaji location, five of the PAHs constituents (fluorene, fluoranthene, Benzo (a) anthracessne, chrysene and benzo (g,h,i) pyrene) were not detected. The summation of PAHs at the Rumuwaji location was $0.28 \mathrm{mg} / \mathrm{L}$ and at the Woji location, six PAHs constituents (acenaphthene, fluorine, phenanthrene, anthracene, benzo (a) anthracene and chrysene) were not detected. The total concentration of PAHs at the Woji location was $0.22 \mathrm{mg} / \mathrm{L}$.

The concentrations of PAHs in water obtained from the creek in the present work is higher than the values observed by Kafilzadeh [1], in a river from Iran, but were within the range of values observed in Mutshundudi and Nzhelele Rivers waters in South Africa [15]. However, these values from the present work are lower than those of Edori and Iyama [10], in the coastline areas of the New Calabar River at the effluents discharge point or drainage outlet and those of Edokpayi et al. [3], from discharged wastewater in an urban area, Vhembe District, South Africa.

The observed values of the individual compounds of the polycyclic hydrocarbons showed that the highest concentrations in the stations were related to benzo (k) fluoranthene (a 5-membered ring) and dibenzo (a,h) anthracene (a 6-membered ring), while fluorine, benzo (a) anthracene and chrysene were not detected in any of the stations. This observation may be related to the nature of formation and origin or source of the PAHs, municipal overflows, manure releases, marine activities, discharges from exhaust of vehicles and marine discharges of PAHs bound chemicals. Furthermore, to these are the presence of chemical industries, wastes directly thrown to the water body, power generating plants used by the multiple industries within the area, dredging activities and other sources that may not have been identified within the area of research that may be regarded as non-point sources may have contributed to the quantity of PAHs observed in the river. This observation is in agreement with the observation of Joil et al. [16], in surficial water samples collected from Todos Os Santos Bay, Brazil.

PAHs are known to have a very short time to reside in water, this is owing to the fact that they have very low solubilities, but possess high octanol-water partition coefficients. The lower molecular weight PAHs are biodegradable and volatile and therefore can easily be lost, but the high molecular weight PAHs undergo photolysis or photo-oxidation and also mixes with suspended particulate matter on the water surface, which the sink to the bottom and settle in the sediment [17].

Table 1. Concentrations of Polycyclic Aromatic Hydrocarbons in Elelenwo River at the different Stations.

\begin{tabular}{lllll}
\hline \multirow{2}{*}{ PAHs (mg/L) } & \multicolumn{2}{l}{ Locations } & \multirow{2}{*}{ Mean \pm SD } \\
\cline { 2 - 4 } & $\mathbf{1}$ & $\mathbf{2}$ & $\mathbf{3}$ & \\
\hline Napthalene & 0.03 & 0.03 & 0.03 & $0.030 \pm 0.00$ \\
Acenapthylene & ND & 0.01 & 0.01 & $0.007 \pm 0.005$ \\
Acenaphthene & 0.01 & 0.01 & ND & $0.007 \pm 0.005$ \\
Fluorene & ND & ND & ND & - \\
Phenanthrene & ND & 0.03 & ND & $0.010 \pm 0.014$ \\
Anthracene & ND & 0.04 & ND & $0.013 \pm 0.019$ \\
Fluoranthene & 0.01 & ND & 0.01 & $0.007 \pm 0.005$ \\
Pyrene & ND & 0.01 & 0.01 & $0.007 \pm 0.005$ \\
Benzo (a) anthracene & ND & ND & ND & - \\
Chrysene & ND & ND & ND & - \\
Benzo (b) fluoranthene & 0.02 & 0.02 & 0.02 & $0.020 \pm 0.00$ \\
Benzo (k) fluoranthene & 0.04 & 0.04 & 0.04 & $0.040 \pm 0.00$ \\
Benzo (a) pyrene & 0.02 & 0.02 & 0.02 & $0.020 \pm 0.00$ \\
Benzo (g,h,i) pyrene & ND & ND & 0.02 & $0.007 \pm 0.009$ \\
Dibenzo (a,h) anthracene & 0.04 & 0.04 & 0.04 & $0.040 \pm 0.00$ \\
Indeno (1,2,3-cd) pyrene & 0.02 & 0.02 & 0.02 & $0.020 \pm 0.00$ \\
E PAHs & 0.19 & 0.28 & 0.22 & $0.230 \pm 0.037$ \\
\hline
\end{tabular}

The quest for oil based products arising from petrochemical activities, capacity productions, and probable utilizations of products are the probable evolving dangers to 
this river environment. This river is close to the petrochemical industry at Akpajo, and a tributary of the Bonny River and also connected to the Okrika River (which is close to the petroleum refining Company). In the view of the surrounding environment and the position of the river, there is the likelihood of being polluted with PAHs and other environmental contaminants. According to Obiakor et al. [18], the government pays deaf ears to the myriads of pollution problem that take place in the Nigerian Niger Delta Areas but is very much concerned with the revenue accruing from the area, thus if the situation as observed is allowed to continue without adequate environmental management and sustainability, the river may sink into high level of PAHs pollution.

The concentrations of the different classes of polycyclic aromatic hydrocarbons in the river water is shown in Table 2. Generally, the higher molecular weight PAHs were higher in concentration when compared to the lower molecular weight PAHs. However, specific group concentrations showed the six-membered rings as the most abundant, which was followed by the five and the two/three membered rings. In each of the stations, the four membered rings were the least in abundance. The observed concentration ranges of the different groupings of the different classes of PAHs observed in the present work is at variance with the observation of Kafilzadeh et al. [19], where the order of abundance of the different categories was $4>5>6>2>3$. Generally, this work revealed that the high molecular weight components were more abundant to than the corresponding low molecular weight PAHs.

The variation in the concentrations of the different PAHs could be ascribed to the molecular weights of the individual class categories and degradation from bacteria. An extensive range of microbes comprising algae, fungi and bacteria have been identified to breakdown PAHs. The LMWP are easily degraded when compared to the HMWP. The degradation of the LMWP is achieved through microbial activities, oxidation, easy penetration into tissues and organs of plants and animals and are easily carried along through drifts (wind and moving water current) $[10,20]$. Furthermore, the higher concentrations of the HMWP have the capacity to pass travel down the water column to sediment bed and mixes with suspended particles, which prevents them from immediate reach of oxidants and degradation agents and so have the tendency to remain for a longer time in the water medium. The rate of intake of hydrophobic PAHs by water dwelling organisms, whether plants or animals correlated with the octanol/water partition coefficient of the compound as well [21]. Thus the different solubilities of polycyclic aromatic hydrocarbons is dependent on the partition coefficient and the weight.

Table 2. Concentrations of Different Ring Classes of PAHs in Water from Elelenwo River

\begin{tabular}{|c|c|c|c|c|}
\hline \multirow{2}{*}{$\begin{array}{l}\text { Ring Type } \\
(\mathrm{mg} / \mathrm{L})\end{array}$} & \multicolumn{3}{|c|}{ Location } & \multirow{2}{*}{ Mean \pm SD } \\
\hline & 1 & 2 & 3 & \\
\hline $2-3$ & 0.04 & 0.12 & 0.04 & $0.067 \pm 0.038$ \\
\hline 4 & 0.01 & 0.01 & 0.02 & $0.013 \pm 0.005$ \\
\hline 5 & 0.08 & 0.08 & 0.08 & $0.08 \pm 0.00$ \\
\hline 6 & 0.06 & 0.06 & 0.08 & $0.067 \pm 0.009$ \\
\hline
\end{tabular}

The origin and sources of the polycyclic aromatic hydrocarbons is shown in Table 3. The diagnostic assessment of the PAHs sources and origin indicated that in station 1, LMW/HMW PAHs analysis indicated a pyrogenic (combustion) source based PAHs and that of Flu /(Flu + Py) analysis also showed that the sources of the PAHs on the surface water from the river were of pyrogenic origin. In station 2, LMW/HMW and $\mathrm{An} /(\mathrm{An}+\mathrm{Ph})$ analysis indicated pyrogenic sources of PAHs contamination of the river. In station 3, LMW/HMW PAHs and Flu /(Flu + Py) analysis both indicated pyrogenic sources of PAHs contamination. The implication of pyrogenic sources of PAHs in the examined river in the present work disagrees with the observations of other authors [10, 22, 23], in surface water from different rivers, where numerous sources were identified as origin of the PAHs. Further to this, the observation of a single source PAHs origin is a result of the numerous industries around the area that are associated with discharge of smoke (gases) from petroleum based products and others from gas flares within the area.

Table 3. Identification of Origin and Sources of PAHs from Elelenwo River.

\begin{tabular}{lllll}
\hline Stations & LMW/HMW & An/(An + Ph) & Flu /(Flu + Py) & BaA/ (BaA + Ch) \\
\hline 1 & 0.267 & - & 1 & - \\
2 & 0.80 & 0.571 & - & - \\
3 & 0.222 & - & 0.5 & - \\
Petrogenic & $>1$ & $<0.1$ & $<0.4$ & $<0.2$ \\
Pyrogenic & $<1$ & $>0.1$ & $>0.5$ & $>0.35$ \\
\hline
\end{tabular}

$\mathrm{LMW}=$ low molecular weight, $\mathrm{HMW}=$ high molecular weight, $\mathrm{An}=$ anthracene, $\mathrm{ph}=$ phenanthrene, flu $=$ fluorine, $\mathrm{py}=$ pyrene, $\mathrm{BaA}=$ benzo[a]anthracene and $\mathrm{ch}=$ chrysene

\section{Conclusion}

The results obtained from the study revealed that the surface water of the Elelenwo River is contaminated by PAHs. The concentrations of the PAHs categories showed that the higher molecular weight PAHs were generally higher than the lower molecular weight PAHs. However, source determination of the determined PAHs showed that Pyrogenic source as the origin of the PAHs in the Elelenwo River. This observation implicated completely anthropogenic influence on the contamination of the river with PAHs. Therefore, adequate efforts should be put in place by concerned bodies and individuals to prevent further increase in the concentration of PAHs in the river, looking at the 
present low levels of their occurrence.

\section{References}

[1] Kafilzadeh, F. (2015). Distribution and sources of polycyclic aromatic hydrocarbons in water and sediments of the Soltan Abad River, Iran. Egyptian Journal of Aquatic Research, 41: 221- 231 .

[2] Wania, F. and Mackay, D. (1996). Tracking the distribution of persistent organic pollutants. Environmental Science and Technology, 30: 390-396.

[3] Edokpayi, J. N., Odiyo, J. O., Popoola, E. O. and Msagati, M. A. T. (2016). Determination and Distribution of Polycyclic Aromatic Hydrocarbons in Rivers, Sediments and Wastewater Effluents in Vhembe District, South Africa. International Journal of Environmental Research and Public Health, 13 (4): 387-349.

[4] Bayoumi, R. A. (2009). Bacterial bioremediation of polycyclic aromatic hydrocarbons in heavy oil contaminated soil. Journal of Applied Science Research, 5 (2): 197-211.

[5] Nasr, I. N., Arief, M. H., Abdel-Aleem, A. H. and Malhat, F. M. (2010). Polycyclic aromatic hydrocarbons (PAHs) in aquatic environment at El Menofiya Governorate, Egypt. Journal Applied Science Research, 6 (1), 13-21.

[6] Nikolaou, A., Kostopoulou, M., Lofrano, G., Meric, S. (2009). Determination of PAHs in marine sediments: analytical methods and environmental concerns. Global NEST Journal. 11 (4), 391-405.

[7] Rhea, D. T., Gale, R. W., Orazio, C. E., Peterman, P. H., Harper, D. D. and Farag, A. M. (2005). Polycyclic aromatic hydrocarbons in water, sediment, and snow, from lakes in Grand Teton National Park, Wyoming. Reston, VA: United States Geological Survey; 29 p.

[8] Ekpete, O. A., Edori, O. S. and Iyama, W. A. (2019). Concentrations of Polycyclic Aromatic Hydrocarbons from Selected Dumpsites Within Port Harcourt Metropolis, Rivers State, Niger Delta, Nigeria. International Journal of Environmental Sciences and Natural Resources, 21 (4): DOI: 10.19080/IJESNR.2019.21.556066

[9] Qiu, Y. W., Zhang, G., Liu, G.-Q., Guo, L.-L., Li, X.-D., Wai, O. (2009). Polycyclic aromatic hydrocarbons (PAHs) in the water column and sediment core of Deep Bay, South China. Estuarine, Coastal and Shelf Science, 83 (1): 60-66.

[10] Edori, O. S. and Iyama, W. A. (2019). Source Identification of Polycyclic Aromatic Hydrocarbons in Water at Point of Effluent Discharge into the New Calabar River, Port Harcourt, Rivers State, Nigeria. International Journal of Environment and Climate Change, 9 (6): 343-349.

[11] Yan, W., Chi, J., Wang, Z., Huang, W., Zhang, G. (2009). Spatial and temporal distribution of polycyclic aromatic hydrocarbons (PAHs) in sediments from Daya Bay, South China. Environmental Pollution, 157 (6): 1823-1830.

[12] Helfrich, J. and Armstrong, D. E. (1986). Polycyclic aromatic hydrocarbons in sediments of the southern basin of Lake Michigan. Journal of Great Lakes Research, 12 (3), 192-199.

[13] APHA, (1998). Standard methods for the examination of water and wastewater. 20 edition publishers: American Public Health Association; American Water Works Association; Water Environment Federation

[14] Ilechukwu, I., Osuji, L. C. and Onyema, M. O. (2016). Source apportionment of polycyclic aromatic hydrocarbons (PAHs) in soils within hot mixed asphalt (HMA) plant vicinities. Journal of Chemical Society of Nigeria, 41 (2): 10-16.

[15] Nekhavhambe, T. J., Van Ree, T. and Fatoki, O. S. (2014). Determination and distribution of polycyclic aromatic hydrocarbons in rivers, surface runoff, and sediments in and around Thohoyandou, Limpopo Province, South Africa. Water SA, 40 : 415-424.

[16] Joil, J. C., Henry, X. C., Marilda, F. and Gisele, M. H. (2012). Persistent toxic substances in surface water of Todos Os Santos Bay, Brazil. Resources and Environment, 2 (4): 141149

[17] Miller, J. S. and Olejnik, D. (2001). Photolysis of polycyclic aromatic hydrocarbons in water. Water Research, 35 (1): 233 243.

[18] Obiakor, M. O., Okonkwo, J. C., Ezeonyejiaku, C. D. and Okonkwo, C. N. (2014). Polycyclic Aromatic Hydrocarbons (PAHs) in Freshwater Media: Factorial Effects and Human Dietary Exposure Risk Assessment. Resources and Environment, 4 (6): 247-259.

[19] Kafilzadeh, F., Shiva, A. H. and Malekpour, R. (2011). Determination of Polycyclic Aromatic Hydrocarbons (PAHs) in Water and Sediments of the Kor River, Iran. Middle-East Journal of Scientific Research, 10 (1): 1-7.

[20] Obayori, O. S. and L. B. Salam, I. B. (2010). Degradation of polycyclic aromatic hydrocarbons: Role of plasmids. Scientific Research and Essays, 5 (25): 4093-4106.

[21] Djomo, J. E., Garrigues P. and Narbonne, J. F. (1996). Uptake and depuration of polycyclic aromatic hydrocarbons from sediment by the zebrafish (Brachydanio rerio). Environmental Toxicology and Chemistry, 15: 1177-1181

[22] Andrea S. N., Gábor, S. and István, V. (2012). Monitoring of polycyclic aromatic hydrocarbons (PAHs) in surface water of the Hungarian upper section of the Danube River. Nova Biotechnologica et Chimica, 11 (1): 27-35.

[23] Olayinka, O. O., Adewusi, A. A., Olujimi, O. O. and Aladesida, A. A. (2018). Concentration of polycyclic aromatic hydrocarbons and estimated human health risk of water samples around Atlas Cove, Lagos, Nigeria. Journal of Health and Pollution, 8 (20): 1- 12. 